\title{
PERCEIVED ORGANIZATIONAL SUPPORT (POS) AND ORGANIZATIONAL COMMITMENT
}

\author{
Dian Ekowati* \\ Mirza Andini \\ Department of Management, Faculty of Economics, Airlangga University
}

\begin{abstract}
Human resource is critically important aspect of organizations. The functions and roles of human resource have developed from administrative matter into supporting the organization to run the managerial and strategic processes. Expertise, knowledge, and experience of existing human resources in organizations should be suitable and allocated at the right time and place. By properly manage the human resources, organization would be able to obtain qualified human resources that have high commitment to organization. High commitment to organizations will lead to a higher effort in supporting organizational success. In order to gain employees' commitment to the organizations, management should put some efforts that ensure all aspects of employees' commitment are fulfilled. This paper is intended to find the significant influence of perceived organizational support (POS) on the dimensions of employee's commitment, comprising of the affective commitment, continuance commitment, and normative commitment, and to find which one of those dimensions are dominantly influence by POS. This paper employed 50 respondents that were sampled using convenient random sampling. Result showed that there were significant influences of POS on employee's commitment either in affective commitment. POS can influence the employees' organizational commitment in all dimensions. This implies that in order to improve organizational commitment, management should provide appropriate managerial supports and ensure that the supports are in line with employee's aspirations and needs.
\end{abstract}

Keywords: Perceived Organizational Support, Organizational Commitment

\section{Introduction}

The successfulness of a service organization in achieving its goals cannot be separated from its effort in providing high quality services to its customers. For that aim, service organizations are required to continuously upgrade and update its service capacities to fit customers' demand. For the sake of organization competitiveness in providing good services, organizations should ensure that they own professional and qualified human resources. Related to this notion, (Dessler 1997: 2) stated that human resource is the most important element for organization in conducting its management functions, such as planning, organizing, staffing, directing, and controlling.

The problem is that how the organization can acquire and maintain qualified human resources that have motivation and commitment to jobs and organization. Maehr (1989:4) stated that effective community needs effective organizations, and effective organizations only exist if there are committed employees. Meanwhile, Newstrom and Davis (1993: 198) argued that organizational commitment reflects employees' trust on organization's vision and mission, willingness to work for organization's goals, and intentions to stay to work in the 
organization. Luthans (1998: 148) also argued that organizational commitment is strong intention to become members of certain organization, a willingness to work for the organization and true acceptance of organization's values and goals. It is also argued that loyal employees tend to be exposed to successful career and life in the organizations. Related to the development of organizational commitment from the employees, Miles as cited in Gomes (1997:40) stated that management cannot only financially reward the employees as human might need and want different form of "reward", such as personal attention, opportunities of being needed as well as decent salaries. All of those things -so called as Perceived Organizational Support (POS) are expected to come from the management the organizations. According to Eisenberger (1986) as cited in LaMastro (2000), Perceived Organizational Support is behaviors or leaders' attitudes, which always give supports and facilitative climate in organizations. Organizational support focuses on the social relationship process in maintaining and developing relationship between employees and organizations. This paper is aimed to explore the relationship patterns between perceived organizational support and employees' organizational commitment.

\section{Literature Review and Hyphotheses Development}

\section{Perceived Organizational Support (POS)}

Eisenberger and Rhoades (2002) inferred that Perceived Organizational Support reflects employees' belief on how much organizations support employees' work and welfare. Meanwhile, Wendel (1994: 91) defined organizational supports as all the things that related to the assistance and relationship amongst working peers and colleagues, which involve the feeling of helping each other and the feeling of need between superiors and subordinates. Furthermore, Robbins (1996: 150) explained that "people get more than just money, or achievement, from their job". For most employees, work also fulfills their need for social interaction. Therefore, it is unsurprising that a kind and supportive working peer can lead to increasing job satisfaction. Moreover, superiors' behavior is also the main determinant of their employees' job satisfaction. With support from the organization, also the individuals inside that organization, it is expected that the employees can actively participate in achieving the organization's goals. Davis (1985:179) argued that, "participation is emotional and mental involvement of employees in a group situation that enable them to give contribution to the group's goal and also to be responsible for it". Based on the abovementioned definitions, it can be concluded that Perceived Organizational Support is when the employees feel confident that their organization cares about them and fully supports them to develop themselves in the organization.

Regarding the important things that have to be present in Perceived Organizational Support, Strauss and Sayles (1990:126) comment that there are three (three) critical factors in support, which are: (1) building a feeling of approval. The overall quality of superiors' behaviors towards the employees, especially trust, can be more important than an action or any combination of actions; (2) developing personal relationship to get to know the subordinates and also to help solving their problems inside, and outside, work; (3) providing a fair treatment by letting every employee knows what is expected of them and by putting discipline in place. Fleishman and Harris (1992) maintained that organizational support for employees could be offered in many ways. The problem is how the organization can give appropriate supports to fulfill its employees' needs. There are three key roles given by Mintzberg (1973) in Sofo (1999; 237) for illustrating the management's role towards their employees, which are Interpersonal 
Role (involving, directing, connecting and being a figure), Informational Role (monitoring, disseminating, and being a speaker), also Decisional Role (resources allocating, negotiating, chaos handling and being an entrepreneur). Support from superiors certainly can influence the tasks that need to be done by the employees and expected to get feedback, so when there is a mistake, a correction to that mistake can be done swiftly. Furthermore, it can be expected that by giving organizational support, employees can increase their achievement in doing their core tasks and ultimately, can do their work more effectively and efficiently. Eisenberger, Huntingon, Hutchison and Sowa (1986: 53-54) argued that organizational support theory is a psychological process as a consequence of organizational support perception:

1. Based on reciprocity norms, organizational support can build employees' responsibility to always looking after the welfare of the organization and willingness to help achieve the organization's aims. The reason for that is the employees feel that they have an invaluable investment and they are responsible for it.

2. Organizational support can fulfill the social and emotional needs of the employees, and the chance that the employees stay as the member of the organization can be increased. The social and emotional needs can be fulfilled because the organization where the employees work always cares about them and gives fairness and appreciation.

3. Organizational support can increase trust from the employees regarding reward from the organization if the productivity of the employees is increased (performance-reward expectancies).

Those processes are advantageous for both organization and its employees. For the employees, the process can increase their job satisfaction and increase their positive mental state. For the organization, the process can increase the employees' effective commitment, increase the employees' productivity, and reduce turnover. Based on the aforementioned brief explanations, it can be stated that support is a critical factor in determining satisfaction and willingness of employees for cooperating in achieving management's targets. As a form of bottom up management, support helps reduce disappointments and pressure felt by many employees when they are confronted with pressure, rigidity, and a sterile job. By reducing frustrations, the support helps creating conditions where people will accept organizational structure with less aversion and more enthusiasm.

\section{Organizational Commitment}

Greenberg and Baron (1993:74) stated that "commitment to organization is an attitude that reflects the position of an individual within the organization, identical and involved with the organization and the individual do no wish to leave the organization". The process of identification in organization is a condition of sharing goals between members of an organization, ownership of the organization and loyalty to the organization. The organization involvement is perceived as individual need to be actively involved in achieving organization's goals and support the goals constantly. Meanwhile, Gibson, Ivancevich, and Donelly (1997:693) comment that "commitment is the feeling of identification, involvement, and loyalty or faithful that are affirmed by an employee towards his or her company. People with commitment towards an organization do not wish to quit their job and accept offer in other organizations". Furthermore, Luthans (1995: 130) argued that "...organizational commitment is most often defined as (1) a strong desire to remain a member of particular organization; (2) a willingness to exert high levels of effort on behalf of the organization; (3) a define belief in, and acceptance of the values and goals of the organization". Based on 
Luthans's opinion, it can be concluded that organization commitment are (1) A strong desire to be a member of a certain organization (2) Willingness to try to improve oneself on the organization behalf, and (3) Assurance and acceptance of values and goals of organization. According to Mowday, Porter and Steers (1982:27), defining organization commitment or working commitment as a power that is relative to individual in identify the involvement of himself or herself, into the organization. Three things, which are, identify this: (1) Acceptance to values and objectives of organizations (2) Readiness and willingness for really trying on behalf of the organization and (3) Desire to maintain membership in the organization (be part of the organization).

Based on those definitions, there is a similarity that commitment to organization contains loyalty and identification towards organization. Commitment to organization is not only about employees' passive loyalty towards the organization, but also involves active relationship where the employees are willing to give all their best efforts to achieve the objective and continuity of the organization. Therefore, it can be concluded that commitment to organization is an individual desire to be the member of the organization, trust, and acceptance of values and objectives of the organization and also willingness to do the best for the organization.

According to Miner (1992: 124), "generally there are two concepts concerning commitment to organization, which reflects two different ways of how people approach their job, profession, organization, and other, which is behavioral commitment that have been studied in great deal by many social psychologists and attitude commitment that deserved attention in organization behavior area".

Roberts and Hunt (1991: 144) provide some approach in explaining commitment to organization. The approaches are as follows:

1. The approach from Etzioni (1961), who maintains that commitment, is rooted from the involvement of employees in the organization. This approach views the commitment and the involvement in the organization by the order from total commitment to no commitment at all. The order can be explained as follows:

a. Moral involvement, based on positive orientation and this is created by values and internalization of objectives and norms of the organization. The employees with moral involvement will increase the level of commitment.

b. Calculative involvement shows the level of commitment that is not strong and based on reciprocal relationship between an individual and an organization. An individual will commit to an organization because he or she gets some benefits and a fair exchange.

c. Alternative involvement shows the lack of commitment to organization. It happens when members of an organization feel confused with the situation where the employees own the organization but do not feel identical with the organization. The employees feel forced by the conditions to own the organization, hence there is no desire from within that psychologically makes the employees feel united with their organization. 
2. The approach by Kanter (1986), who argues that different types of commitment are gathered from different behaviors. Three different kinds of approach according to Kanter (1986) are:

a. Continuance commitment is the dedication of the member of the organization to the continuity of that organization.

b. Cohesion commitment is the closeness to social relationship within organization.

c. Control commitment, is the member's closeness towards the organization norms that shape behaviors accordingly. This type of commitment occurs when employees believe that the norms and values of the organization are the important guide to their behavior.

3. The approach by Staw and Salancik (1977) that views commitment based on differences that are mentioned by organizational researchers and social psychologists. This approach views commitment as follows:

a. Attitudinal commitment, which focuses on how employees identify themselves with the objectives and values of the organization. Individual commitment to organization is based on the desire from the individual and this is a commitment from the organization's point of view.

b. Behavioral commitment, which focuses on how someone's behavior attracting himself or herself to the organization. Once the behavior shows commitment, people have to adjust their behavior, which in turn influence the subsequent behaviors (where behavior shapes attitude and shaped attitude will shape the behavior).

Relating to dimensions in commitment, Allen and Meyer in Luthans (195: 127) shows three dimensions that can be used to measure commitment of members of an organization or employees. The dimensions are:

1. Affective commitment, which is emotional involvement of the employees to organization. This commitment is affected and/or developed, if the employees' involvement in the organization is proven to be a satisfactory experience, which can give them chance to do the job better or create the chance to get valuable skills. Greenberg and Baron (1993: 170) state that affective commitment is almost similar to orientation approach to similarity of objectives of individual and organization that shows the strength of someone's willingness to keep working for the organization because that person has the same vision as the organization and, indeed, is willing to do it.

2. Continuance commitment (commitment based on the costs that might incurred as employees leaving the organizations). This commitment is affected and/or developed when an individual invests. The investment will be lost or reduced in value if the individual switch to other organization. Greenberg and Baron (1993: 175) contend that this commitment is close to orientation approach that shows the strength of someone's need to continue working for the organization.

3. Normative commitment (involvement of the employees' feeling towards tasks in the organization). Normative commitment is infuenced and/or developed as the results from internalization normative pressures to do a series of certain actions and the receipt of benefit that causes the feeling of obligation that has to be paid back. 
The employees with strong affective commitment will stay in the organization because they want to. The employees with continuance commitment stay in the organization because they need to. Meanwhile, the employees with strong normative commitment stay in the organization because they ought to do it. Allen and Meyer (1993) think that people can accept the employees relationships better if all of the commitment types are taking into account together. This research employs the concept of commitment by Allen and Meyer (1993). Moreover, the theory--measured by Organizational Commitment Questionnaire (OCQ) helps to find which type of commitment that is most eminent, affective, continuance, or normative.

Nowday, Porter, and Steers (Griffeth 1995: 95) develop a commitment model in organization that links the factors influencing commitment to organization with output or consequence of organization commitment. Factors affecting commitment to organization are: personal characteristics (eg. age, position, etc), role and job characteristic (eg. Job identity and feedback), structural characteristic (formality and decentralization) and working experience (including group cohesiveness) will create consequence commitment to organization in the form of desire to stay in the organization, absence level, ownership and be part of the organization and willingness to give the best effort for the organization.

Greenberg and Baron (1993: 176) add two other factors that affect commitment, which are chance to get alternative job and how the organizational treat new employees can also affect the commitment to organization. Alternative chance of job is related to individual chance to get other job. The higher the individual perception regarding the chance for getting other job, the lower the individual desire to commit. Organization's treatment to the employees can affect commitment because organization can do many things to help new employees to learn about the organization and be a productive member of the organization. Allan and Meyer (1993) argue that each component has different foundation. The employees with high affective component still join the organization because they want to be the member of the organization. The employees with high continuance component still join the organization because they have to. Employees have different behavioral foundation according to their organization commitment. The employees who have affective commitment have different behavior from those with continuance commitment. The employees who want to be member of the organization are willing to give their best effort according to the purpose of the organization. In contrast, the employees who have to be member of the organization will avoid financial loss and other loss, so they might not give their best effort. Meanwhile, normative component is created as a result of socialization experience depends on how the employees' feelings of obligation are. Normative component creates the feeling of obligation to return what employees have received from the organization.

Relationship between Perceived organizational Support (POS) and Organization Commitment

Eisenberger, Fasolo, and Davis-LaMastro (1990) maintain that POS is positively related to offering constructive suggestions for organization improvement and affective organization commitment when translated; POS tends to have positive relationship towards constructive comments to improve the whole organization and also toward affective organization commitment. Furthermore, Organ (1988) also contends that "employees with higher level of POS are likely to be more committed and possibly more willing to engage in extra role or "organization citizenship" behaviors". This is similar to a study by LaMastro (2000) that 
demonstrates that here is a significant effect of POS towards organization commitment, especially towards affective commitment. Based on the above explanation, hypotheses that will be tested in this research are:

1. There is a significant effect of POS on employees' affective commitment

2. There is a significant effect of POS on employees' continuance commitment

3. There is a significant effect of POS on employees' normative commitment

\section{Research Methodology}

This research uses quantitative methodology approach, that uses rationalization process from a phenomena that occurs and measures variables that are being researched. Quantitative approach attempts to reach a generalized conclusion. There are two types of variables used in this research. Perceived Organizational Support (POS) represent the exogenous variable, while the endogeneous variables are the employees' organizational commitment (Affective, Continuance, and Normative Commitment). This research uses Eisenberger' POS (1990) with 12 indicators.

Population of this study is 249 employees of operational department with total distributed questionnaire for 50 respondents, that were sampled using convenient random sampling. From that number, $72 \%$ of them are men. From working period standpoint, $44 \%$ of the respondents have been working for more than 7 years.

\section{Statistical Result and Discussion}

From questionnaire validity test, all indicators item are valid and the reliability test reveals that all of the variables have Cronbach's Alpha more than 0.8 , which means that all variables are reliable. For path analysis test, the assumption that data is normally distributed and there is no outlier also shows good results. Data is normally distributed if it has CR skewness and kurtosis value at \pm 2.58 , univariately and multivariately. The analysis demonstrates that normality test for all of the variables has CR value less than +2.58 except for variable perceived organizational support that has a good CR value at skewness and kurtosis more than +2.58 . Although there are variables that are not normally distributed univariately, on multivariate test the data is normally distributed with CR value of 2.524. According to Hair (1998), the requirements of path analysis test is a normal multivariate. Hence, though the data is not normal univariately, the normal multivariate requirement is fulfilled.

Meanwhile, the results from outlier test show that in multivariate outlier test, the highest score of Mahalanobis D Square is 22,088 lies on the $9^{\text {th }}$ data, while the minimum score of Mahalanobis D Square is 0,44 . The highest standard based on Chi Square score table is 18,467 and since the Mahalanobis D Square score is bigger than the Chi Square table, the ninth data is an outlier data. Although there are some data with outlier multivariate on the ninth data, data elimination is not necessary since the normality test on multivariate is already fulfilled the normal requirement. 

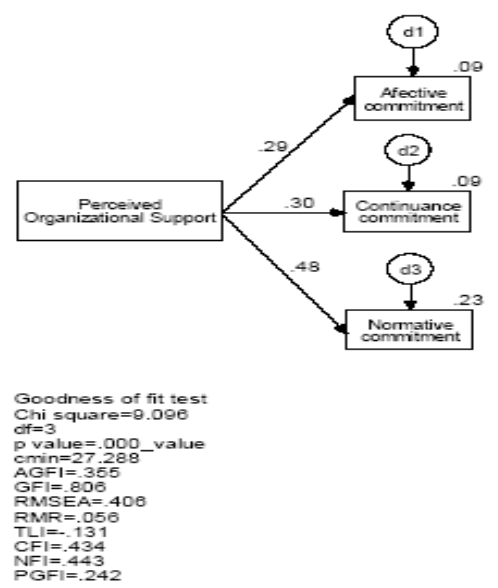

Figure 1

Path Analysis Diagram

Table 1

Path coefficient score for each of the variables

\begin{tabular}{lcc}
\hline \multicolumn{1}{c}{ Variable } & $\begin{array}{c}\text { Nilai Standardized } \\
\text { coefisien }\end{array}$ & $\begin{array}{c}\text { Ranking Pengaruh } \\
\text { Dominan }\end{array}$ \\
\hline $\begin{array}{l}\text { Perceived organizational support } \\
\text { Affective commitment }\end{array}$ & 0.294 & 3 \\
$\begin{array}{l}\text { Perceived organizational support } \\
\text { Continuance comitment }\end{array}$ & 0.301 & 2 \\
$\begin{array}{l}\text { Perceived organizational support } \\
\text { Normative commitment }\end{array}$ & 0.476 & 1 \\
\hline
\end{tabular}

Based on standardized coefficient score, variables with dominant impact can also be revealed. Variables with dominant impact can be detected from the biggest path coefficient score. Hence, the biggest impact is from POS to normative commitment.

Table 2

Determinant Coefficient Scores

\begin{tabular}{|c|c|c|}
\hline \multicolumn{2}{|c|}{ Variabel } & $R^{2}$ \\
\hline Perceived organizational support & Affective commitment & 0.087 \\
\hline Perceived organizational support & Continuance commitment & 0.091 \\
\hline Perceived organizational support & Normative commitment & 0.226 \\
\hline
\end{tabular}


The parameter of whether there is a partial influence or not can be gathered from CR value (Critical Ratio). In this research, parameter that is used as benchmark is by comparing calculated significant values with standardized significant of 0.05 .

Table 3

Hypotheses Testing Results

\begin{tabular}{lcccc}
\hline & Variabel & CR & CR standard & Sig. \\
\hline POS & Affective commitment & 2.155 & 1,96 & 0.031 \\
POS & Continuance commitment & 2.210 & 1,96 & 0.027 \\
POS & Normative commitment & 3.784 & 1,96 & 0.000 \\
\hline
\end{tabular}

The Impact of Perceived Organizational Support (POS) on Affective Commitment

Statistical result shows that Perceived Organizational Support does have an impact on affective commitment, which can be seen from CR value of 2,155 with significant level of 0,031 . Having this result, the first hypothesis is accepted. Affective commitment refers to the emotional belongingness and involvement of employee to work for organizations. Research shows that the organization provides support for its employees through ranges of briefings, trainings, and reward mechanisms. With briefings, managers can learn about difficulties faced by their subordinates. It is expected by having series of briefings, managers can discuss with employees to find some solution alternatives as well as discuss the possibilities of implementation of such alternatives. Moreover, during the briefing sessions, managers can also bring about the issue of new product knowledge in the organizations. This will help employees to better understand the organization as well as give them foundations to deal with customers' enquiries. Meanwhile, training programs conducted by the organization is intended to build standardized competent employees. This will relate to the new psychological contract between organization and employees, which instead providing job securities, organization tends to provide facilities to improve employees' employability. As for the employees, having provided trainings, they felt that organization is willing to share with them new experience as well as giving them opportunities to improve their knowledge, skill, and ability. Related to reward mechanism as one kind of POS, the organization is providing both financial and non-financial reward. During the interview sessions, the management revealed that organization tried to comply with government regulation on minimum wage rate. This -according to the management-will at least give impression for the employees that they are being concerned, appreciated, and equally treated by the organization. With all of those organizational supports, employees are expected to feel that they belong to the organization. When employees feel that they are part of the organization, it can be expected that employees will be willing to work hard for the organization. This condition can be achieved, as employees might not merely think that jobs are bunch of obligations, but more as self-willingness to work. On the other words, employees with strong affective commitment will tend to stay in the organizations because they want to. Research shows that the highest mean is 3,22 for the indicator stating that employees will be likely to feel happy to work for the organization until their retirement times, while the lowest mean is for the indicator stating that organization is not deserved to have employees' loyalty (2.40). Based on those results, it can be inferred that as long as employees feel that they shares the same goals with the organization and the organization does concern about their welfare and employability issues, then the organization will have employees' commitment and loyalty to the organization. 
The Influence of Perceived Organizational Support (POS) on Continuance Commitment

Research shows that Perceived Organizational Support has significant influence on continuance commitment which is shown by CR value of 2,210 with significancy level of 0,027 . Thus, hypothesis stated that Perceived Organizational Support has a significant influence on continuance commitment can be accepted. In continuance commitment, employees tend to think about the liabilities occurs if they leave the organizations. It can be understood here as if an employee leave an organization, he or she will loose parts of his/her potential welfare issues, such as working experience reputation, job security or stability, as well as both financial and non financial facilities that he or she might get if he/she stay in the organization. Thus, it can be inferred from these that employees with strong continuance commitment will stay in the organization because they need to. This organization is also known as one of the companies with "Zero Conflict" predicate, which encourages employees to stay in the organization. Good communication has created warm superior-subordinate relationship. This situation, somehow, influence employees to reconsider their decisions to switch to other organizations. They might think that they might not be able to get similar benefits with what they have now if they work on other organizations.

The Influence of Perceived Organizational Support (POS) on Normative Commitment

Research shows that Perceived Organizational Support has significant influence on normative commitment which is shown by CR value of 3,784 with significancy level of 0,000 . Thus, hypothesis stated that Perceived Organizational Support has a significant influence on normative commitment can be accepted. Thus, hypothesis stated that Perceived Organizational Support has a significant influence on normative commitment can be accepted. Normative commitment refers to the feeling of the employees to stay in the organization because they think that they have obligations to organizations and normative pressure internalization to conduct series of certain behaviors. With those all organizational support such as briefing and training, the employees will feel that organization does concern about their existence and try to enrich employees' potential. In turn, these efforts will create condition of moral obligation to "pay back" to the organization for what the organization have done to them. Furthermore, organization does implement controlling mechanism to ensure that employees do the job as they are required and expected to do. Once employees cannot be able to fulfill the expectation, organization will bring about some punishment for them. Having this mechanism, employees tend to follow and obey rules on what should and should not be conducted on their jobs. These are done by the employees to avoid potential punishments. Thus, it can be inferred that employees will stay in the organization because they ought to.

The Influence of Perceived Organizational Support (POS) on Employees' Organizational Commitment

Generally, from those discussions, it can be seen that in this research perceived organizational support do have impact on employees' organizational commitment with coefficient of determination of $40,4 \%$. This result is aligned with Eisenberger, Fasolo, and LaMastro (1990) which argued that POS is positively related to offer constructive suggestions for organizational improvement, and affective organizational commitment". At this term, it means that Perceived Organizational Support tend to have positive relationship toward constructive ideas 
to improve organization's performance as well as toward organizational commitment. Organ (1988) stated that employees with higher levels of POS are likely to be more committed and possibly more willing to engage in extra role or "organizational citizenship" behaviors". This would mean employees with high organizational support will tend to have more commitment to the organization and more intent to get involved in special organizational roles. When the organizational supports are existed, it is expected that employees will be willing to actively participate in achieving organization's objectives. Davis (1985:179) defines that participation is emotional and mental involvement of the employees in group situations that will engage them to contribute to group cohesiveness, group's objectives as well as being responsible for that aims. Having Perceived Organizational Support, employees will feel that organization concerns for their existence and give full support to develop employees' competencies. The existence of emotional involvement to be responsible to organization to achieve goals and develop one self in the organization are becoming resources to raise commitment, as commitment itself is defined as attitudes that reflect the degree of how individual is identified and involved with the the organization nad not have any intention to leave the organization. Meanwhile, the involvement to organization is viewed as an intention of individual to actively involved to achieved organization objectives and will always support the objectives (Greenberg dan Baron, 1993:74).

The difference between this research and one of LaMastro (2000) lies in the variable that is dominantly influenced by POS. LaMastro's research (2002) shows that the dominant variable is affective commitment, while this research reveals that POS is dominantly affecting normative commitment (standardized coefficient $=0,476$ ) compared to the standardized coefficient of 0.294 for affective commitment. This might be potentially caused by the possibility that the perceived organizational support is less able to trigger emotional involvement of the employees (affective commitment), so that employees do their jobs as obligations and compliances to organization's rules. Besides, with the existence of controlling mechanism, organization is much easier to control employees' behavior to fit to what are expected by the organization. It can be inferred here that the reason of the employees to stay in the organization is not because they want to or they need to, but rather, the employees might think that they ought to stay in the organization

\section{Conclusion}

It can be concluded that organization has been proved to provide good organizational support, one of the most significant is the implementation of routine programs to improve employees' competencies and provide zero conflict working environment. It is suggested to the organization to sustain the zero conflict working environment by conducting activities that lead to the feeling of togetherness and belongingness as well as providing support to enhance high performing system. Having these done, it is expected that employees will be able to enrich their skills and abilities that will in turn, be dedicated to the organization. Furthermore, the existence of POS in the organization will make employees feel of being concerned and become parts of organization's life, so that employees will have more responsibilities towards jobs and the sustainability of organization's life. 


\section{References}

Davis, Keith dan John W. Newstrom. 1985. Perilaku dalam Organisasi. Jilid 1. Terjemahan. Jakarta: Penerbit Erlangga.

Eisenberger, R., R. Hutchison, and D. Sowa. 1986. Perceived Organizational Support, Journal of Applied Psychology, 75: 51-59

.................. \& L. Rhoades. 2002. Perceived Organizational Support: A Review of the Literature, Journal of Applied Psychology, 87: 689-714

Ferdinand, Augusty. 2002. Structural Equation Modelling dalam Penelitian Manajemen: Aplikasi Model - Model Rumit dalam Penelitian untuk Tesis \& Desertasi Doctor. Edisi 2. Semarang: BPUNDIP.

Fleishman, E., and E. Hariss. 1992. Patterns of Leadership Behavior Related to Employee Grievances and Turnover, Personnel Psychology. 15:43-56.

French, Wendell. 1994. Human Resources Management. Third Edition. Boston: Houghton Mifflin Company.

Gibson, L. James, Ivanchevich M. John, Donelly. 1997. Organisasi dan Manajemen: Perilaku, Struktur, Proses. Edisi Keempat. Terjemahan. Jakarta: Erlangga.

Greenberg, G., and R.A. Baron. 1993. Behavior In Organizations, Third Edition, New Jersey: Prentice Hall Inc.

Griffeth, Hom. 1995. Employee Turnover: South-Western Series in Human Resources Management. Boston: Houghton Miffin Company.

Hadi, Sutrisno. 1991. Administratif Butir Untuk Instrumen Diagram Test dan Skala Nilai Dengan BASICA. Yogyakarta: Andi Office.

................ 2001. Metodologi Research. Jilid 2. Yogyakarta: Andi Offset.

Hair, Jr.J.F., R.E.Anderson, R.L. Tatham and William. C.Black. 1995. Multivariate Data Analysis with Reading. 4th edition. New Jersey: Prentice Hall, Engelwood Cliff.

Indriantoro, Nur dan Bambang Supomo. 1999. Metode Penelitian Bisnis Untuk Akuntansi dan Manajemen. Edisi ke-1. Yogyakarta: BPFE.

Kelloway, D.F. 1998. Multivariate Statistical Methods. Auckland: Mc Graw-Hill. Hill Inc.

Kline, Rex B. 1998. Structural Equation Modeling. New York London: The Guilford Press.

Kuntjoro, Zainuddin Sri. 2002. Artikel Komitmen Organisasi. www.epsikologi.com/masalah/250702.htm. diakses 18 Agustus 2005. Pk. 13. 15.

Luthans, Fred. 1995. Organizational Behavior. Seventh Edition. New Jersey: Englewood Cliff: Prentice Hall Inc.

Malhotra, Naresh K. 1999. Marketing Research: An Applied Orientation. Third Edition. Prentice Hall International, Inc.

Meyer, J.P., N.J. Allen, and C.A. Smith. 1993. Commitment to Organizations Occupations: Extension and Test of a Three-Component Conceptualization, Journal of Applied Psychology, 78 (4), p: 538-551

Miner, John B. 1992. Industrial-Organizational Psychology. International Edition, New York: Mc Graw-Hill Inc.

Mowday, R.T., L.W. Porter, and R.M. Steers. 1982. Employee-organizational linkages: The Psychology of Commitment, Absenteism, and Turnover, San Diego : Academic Press.

Putra, Mayhendra Syafrudin. 2005. Pengaruh Komitmen dan Dukungan Organisasi terhadap Kinerja Karyawan pada PT. Duta Trasindo Pratama Surabaya. Fakultas Ekonomi Universitas Airlangga. Skripsi Sarjana Strata 1 yang Tidak Dipublikasikan.

Reaves, C.C. 1992. Quantitive Research for The Behavioral Sciences. Singapore: John Wiley and Sons, Inc. 
Robbins, S. 1996. Perilaku Organisasi: Konsep, Kontroversi, Aplikasi. Edisi ketujuh. Terjemahan. Jakarta: Prehalindo.

Robert, K.H., and D.M. Hunt. 1991. Organizational Behavior. Second Edition, Boston: Pws-Kent Publishing Company.

Singarimbun, Masri dan Sofian Efendi. 1995. Metode Penelitian Survey. Cetakan Kedua. Jakarta. PT. Pustaka LP3ES Indonesia. (Agustus)

Steers, Richard M. 1985. Managing Effective Organizations. Boston: Kent Publishing Company.

Sofo, F., 1999. HRD : Perspective, Roles and Practices. Business \& Professional Pub. NWS. Australia.

Solimun, Dr., M.S. 2002. Multivariate Analysis : Structural Equation Modelling (SEM) Lisrel dan Amos. Malang: Penerbit Universitas Negeri Malang.

Strauss, G., and L. Sayles. 1990. Manajemen Personalia: Segi Manusia dalam Organisasi. Edisi kedua. Terjemahan. Jakarta: PT. Pustaka Binaman.

Sugiyono, 1999. Statistika Untuk Penelitian. Bandung: CV. Alfabeta Sugiyono dan Eri Wibowo. 2002. Statistika Penelitian dan Aplikasinya Dengan SPSS 10.0 for Windows. Bandung: Penerbit ALFABETA.

Sumarsono, H. M. Sonny. 2004. Metode Riset Sumber Daya Manusia. Edisi Pertama. Yogyakarta: Graha llmu.

\footnotetext{
" Dian Ekowati, adalah staff pengajar dan peneliti di Fakultas Ekonomi, Universitas Airlanga, Surabaya. Saat ini penulis sedang menyelesaikan pendidikan doktornya di The York Management School, The University of York, Heslington, York, United Kingdom. Bidang minat penulis adalah dalam bidang manajemen sumber daya manusia, organization system/design, knowledge management and change. Mirza Andini adalah asisten dosen dan asisten peneliti di Fakultas Ekonomi, Universitas Airlangga. Saran dan kritik yang membangun bisa langsung menghubungi penulis melalui email: de515@york.ac.uk dan didien_e@yahoo.com.
} 